\title{
LEGISLATIVE NORMS TO CONTROL CANNABIS USE IN THE LIGHT OF ITS PREVALENCE IN THE CZECH REPUBLIC, POLAND, SLOVAKIA, AND HUNGARY
}

\author{
Róbert Čecho, Tibor Baška, Viera Švihrová, Henrieta Hudečková \\ ${ }^{1}$ Department of Public Health, Jessenius Faculty of Medicine in Martin, Comenius University in Bratislava, Martin, Slovak Republic
}

\section{SUMMARY}

Objectives: Cannabis control legislation ranks among key measures to prevent social-health impacts of its use. The article qualitatively analyses respective legislation in the Czech Republic, Poland, Slovakia, and Hungary (Visegrad Four, V4) considering level of decriminalisation of cannabis use in relation to current epidemiological situation.

Methods: Qualitative analysis of the cannabis control legislation in V4 countries from 1995 to 2016 focusing on criminal liability, differentiation of cannabis from other illicit substances, definition of a small amount intended for personal use, sentences for possessing and dealership of the drug.

Results: Slovakia, Hungary and Poland share similar restrictive legislative approach throughout the studied period. In the Czech Republic, the situation has been different and since 2010 cannabis has been further decriminalised: possession of defined small amount of drug not being under prosecution and milder sentences for cannabis than for other illicit psychoactive substances.

Conclusion: Although the prevalence of cannabis use among adolescents is the highest in the Czech Republic, partial decriminalisation did not show further increase. Slovakia, Hungary and Poland show different trends in epidemiological situation despite of similar legislative approach. Results indicate that beside legislation other social factors play a role and measures to change attitudes and decrease social tolerance are important.

Key words: cannabis, legislative measures, decriminalisation, substance use, Visegrad Four

Address for correspondence: R. Čecho, Department of Public Health, Jessenius Faculty of Medicine in Martin, Malá Hora 4B, 03601 Martin, Slovak Republic. E-mail:cecho2@uniba.sk

https://doi.org/10.21101/cejph.a5019

\section{INTRODUCTION}

Use of psychoactive addictive substances ranks among the topical public health issues in developed countries. Among them, cannabis is the most frequently used illicit substance in Europe (1). Although social-health burden of cannabis use is not as large as in case of alcohol and tobacco, its public health impact cannot be underestimated. While occasional use of marihuana not necessarily results in health effects, its regular use is associated with numerous consequences such as increased risk of mental disorders including addiction, altered development in adolescents (2), respiratory diseases (3), as well as social effects such as affected school performance, risk-taking and delinquency (4). Moreover, there is an association between the use of cannabis and the use and misuse of other illicit drugs $(5,6)$.

Restrictive legal measures, namely sentences for distribution and use of illicit drugs, play a crucial role in decreasing availability of cannabis and thus control its use (7). Currently, public debates on partial decriminalisation, i.e. legalization for recreational use are on increase. Such legislative changes are justified to prevent inappropriate public stigmatisation of occasional recreational users (8). Analysis using data on adolescent use in 38 countries of Europe and North America showed positive correlation between decriminalization level and prevalence of regular cannabis use (9). However, the results were rather heterogeneous indicating that specific historical and cultural background factors play an important role (9).

Several European drug policy analyses indicate, that there is no direct correlation between the level of criminalisation or toughening of the drug law and the level of drug use (and vice versa) (7, $10-12)$. However, there is still scarcity in relevant comparative analyses of legislation $(8,13)$, and experiences from Americas should be only very carefully implemented in specific conditions of transition countries in Central Europe.

To monitor availability of cannabis, lifetime use in adolescents can be considered as an appropriate indicator (14). In this aspect, an adolescent population is a key target group since this age is particularly linked to initiation and development of illicit substance use (15). The European School Survey Project on Alcohol and Other Drugs (ESPAD) provides relevant and representative epidemiological data to evaluate epidemiological situation and extent of the problem in the community (16-21). It seems that popularity of cannabis in V4 countries is on increase, also the highest prevalence of lifetime use among adolescents can be seen in the Czech Republic (Fig. 1).

This paper analyses the development of cannabis use in the adolescent population in the Czech Republic, Poland, Slovakia, and Hungary - known as the Visegrad Four (V4) in the light of relevant legislation. The V4 forms a geographical unit linked together through a common history as well as close social and economic 


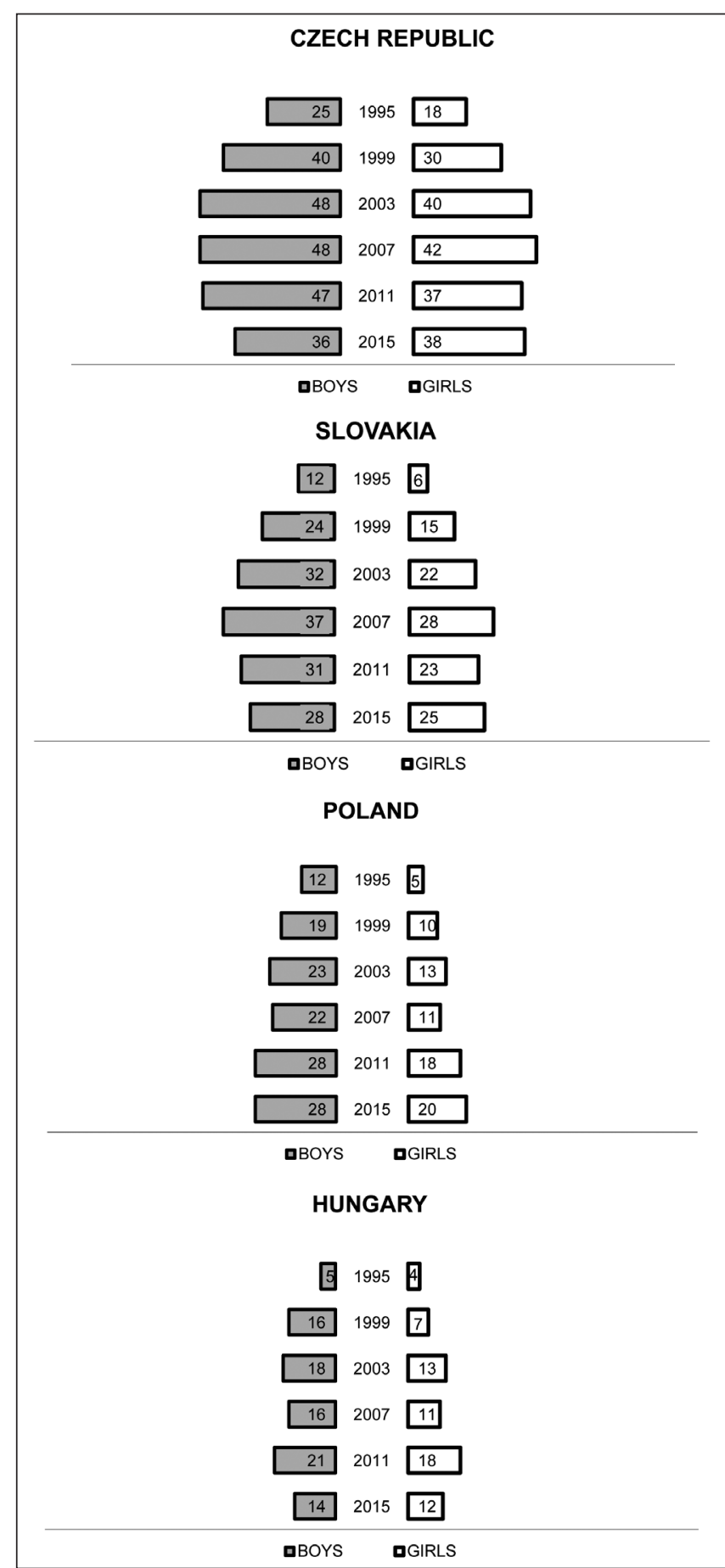

Fig. 1. Lifetime cannabis use among 15-16 years old adolescents in the Czech Republic, Poland, Slovakia, and Hungary in percentages (ESPAD 1995-2015).

relations. Compared to Western Europe, there is a shorter history of cannabis use in these countries and its introduction occurred during turbulent political, economic and social transition following the fall of communist regime in 1989.

The goal of this article is to qualitatively analyse indicators of strictness of legislative norms related to distribution, possession and use of cannabis in the Czech Republic, Poland, Slovakia, and Hungary from 1995 until now in the light of epidemiological situation regarding cannabis lifetime use among adolescents. Analysing of legislation differences in these countries can contrib- ute to the identification of effective preventive measures common and unique to the V4.

\section{MATERIALS AND METHODS}

A qualitative analysis of the development of legislation norms regarding sentences for distribution, possession and use of cannabis in the Czech Republic, Poland, Slovakia, and Hungary from 1995 until now was carried out. The following indicators of strictness of legislation were tracked:

- Level of criminalization of cannabis use. It means differentiation of cannabis from other illicit substances, reclassification of use and possession for personal use from criminal act to a misdemeanour or to repeal criminal liability for it.

- Definition of a "small amount of drug for personal use". It means determined certain amount of the drug which possession is still unauthorised but considered differently than possession of larger amount. Usually, while possession of larger amount of the drug is considered a criminal act, possession of small amount bellow defined level is considered a misdemeanour.

- Penalties for possessing certain amount of cannabis for further distribution.

Indicators of legislation were taken from the information portal of the European Monitoring Centre for Drugs and Drug Addiction (EMCDDA) database $(7,22)$, and national legislation (i.e. criminal code).

\section{RESULTS}

The focus of the paper was to evaluate relationships between the legislation of V4 countries and prevalence of cannabis use. Table 1 summarizes the main differences in legislation in V4 countries. In the Czech Republic, throughout the studied period, relevant legislation underwent several significant changes. The possession of narcotic drugs was not a criminal offence in the Czech Republic from 1990 to 1998. In 1997, the Amendment No. 112/1998 Coll. defined criminal penalties for drug possession, but only for cases when the quantity was "greater than small" (23-25). No other criteria were introduced to determine quantity of cannabis, thus leaving interpretation completely on judicial practice (12).

However, Act No. 40/2009 of the Criminal Code came into force in 2010. This norm, unlike the previous legislation, established lower penalties for unauthorised possession of cannabis for personal use only. The Government also defined quantity of cannabis (the amount "greater than small") which can be possessed without any given criminal penalties. According to Government Decree No. 467/2009 Coll., $15 \mathrm{~g}$ of dry matter and $5 \mathrm{~g}$ of hashish was the maximum amount of possessed drug (12).

After 2013, selected drugs and their quantities have been changed by the Supreme Court. The legislation defines max. 10 grams of dry marijuana and 5 grams of hashish as a small amount, its possessing is considered a misdemeanour and is financially penalized up to 15,000 CZK (554 EUR) but not by imprisonment. Possession of a larger amount is considered an offence punishable by imprisonment up to 1 year. In case of dealership, the penalty is usually imprisonment up to 5 years $(26,27)$. 
Table 1. Selected characteristics of legislation dealing with cannabis in the Czech Republic, Poland, Slovakia, and Hungary (EMCDDA, 2016)

\begin{tabular}{|c|c|c|c|c|c|}
\hline Countries & $\begin{array}{l}\text { Decriminalisation } \\
\text { of cannabis use }\end{array}$ & $\begin{array}{l}\text { Decriminalisation of } \\
\text { cannabis possession } \\
\text { in small amount }\end{array}$ & $\begin{array}{l}\text { Definition of small } \\
\text { amount for personal } \\
\text { possession }\end{array}$ & $\begin{array}{l}\text { Sentence for personal } \\
\text { possession }\end{array}$ & $\begin{array}{l}\text { Sentence for sale, } \\
\text { supply, trafficking }\end{array}$ \\
\hline Czech Republic & yes & yes & $\begin{array}{c}\text { yes } \\
\text { Marijuana } \leq 10 \mathrm{~g} \\
\text { Hashish } \leq 5 \mathrm{~g}\end{array}$ & $\begin{array}{l}\text { Small amount: Misde- } \\
\text { meanour - fine up to } \\
\leq 15,000 \text { CZK ( } \leq 554 € \text { ) } \\
\text { Larger amount: Impris- } \\
\text { onment up to } 1 \text { year } \\
\text { (if not present } \\
\text { aggravating factors) }\end{array}$ & $\begin{array}{c}\text { Imprisonment from } 1 \text { to } \\
5 \text { years (if not present } \\
\text { aggravating factors) }\end{array}$ \\
\hline Slovakia & no & no & no & $\begin{array}{l}\text { Imprisonment up } 1 \\
\text { to } 5 \text { years }\end{array}$ & $\begin{array}{c}\text { Imprisonment up } 10 \text { to } \\
20 \text { years }\end{array}$ \\
\hline Hungary & no & no & $\begin{array}{c}\text { yes } \\
\leq 1 \mathrm{~g} \mathrm{THC}\end{array}$ & $\begin{array}{l}\text { Imprisonment up } \\
\text { to } 2 \text { years }\end{array}$ & $\begin{array}{l}\text { Imprisonment up } 5 \text { to } \\
20 \text { years }\end{array}$ \\
\hline Poland & yes & no & no & $\begin{array}{l}\text { Imprisonment up } \\
\text { to } 1 \text { year }\end{array}$ & $\begin{array}{l}\text { Imprisonment up to } \\
10 \text { years }\end{array}$ \\
\hline
\end{tabular}

In Slovakia, the issue is covered by the Act No. 139/1998 Coll. Possession and consumption of any amount of cannabis is considered a criminal act. Possession is penalised by imprisonment up to 5 years. The legislation does not define any small amount, however, the amendment passed in 2005 (Act. 300/2005 Coll.) includes term of "a usual single dose for personal use". This dose is derived from average weight of a cannabis cigarette, i.e. usually up to $0.5 \mathrm{~g}$ and multiple of $3-10$ such doses are considered an amount for personal use. Possession of such amount can be exculpated or only conditional imprisonment sentence is imposed. However, no exact amount is defined in the Act and a court decides individually based on a forensic expert opinion (28). On the other hand, serious criminal acts (sale, distribution, etc.) are punished by imprisonment from 10 to 20 years (28). In Slovakia, although the legislation does not differentiate between cannabis and other illicit substances, in criminal proceedings the cannabis is usually considered less strictly.

In Hungary, legislation dealing with illicit substance use came into force in 1995 as a part of the Criminal Code. Originally, in case of a criminal act of possession of the addictive drug, the court had possibility to suspend prosecution when an offender underwent 6-months long obligatory treatment. In 1999, sentences became more rigorous. Namely, previous possibility to undergo treatment instead of imprisonment was significantly restricted and the diversion was allowed only for addicted users. The amendment coming into force in 2002 made using and possessing of cannabis more liberal. It returned possibility to undergo treatment instead of imprisonment for all first-time offenders and not only for addicted. The last amendment, coming into force in 2013 (Act $\mathrm{C}$ of 2012), made the legislation more rigorous. According to it, possession and consumption of cannabis is considered a criminal act alike possession and consumption of other illicit substances such as morphine, cocaine etc. Import, export and sale of cannabis are penalised by imprisonment from 5 to 20 years. However, the legislation defines the small amount of cannabis for personal use as a dose containing maximum $1 \mathrm{~g}$ of active tetrahydrocannabinol (THC). It equals $12-100 \mathrm{~g}$ of cannabis (1-8\% of THC). In such case, the penalty is imprisonment up to 2 years. However, the prosecution can be suspended for a first-time offender if the individual is addicted and complies with a specialised 6-months long treatment (29).

In Poland, the most significant legislative changes were passed in 2005 and 2011. In 2005, educational and preventive measures were defined as well as competencies of courts in imposing sentences. It means a possibility to impose a specialised treatment for the delinquent. The latest Criminal Code amendment came into force in 2011. According to it, mitigation circumstances are taken into consideration. Although consumption of cannabis is no longer considered a criminal act, cannabis possession is still penalised by imprisonment of up to 3 years. The legislation does not define a small amount of the drug. Moreover, the legislation does not differentiate between cannabis and other illicit substances. The prosecution can be suspended if the defendant complies with a specialised treatment. Prosecutor has an option to suspend prosecution for possession case which involves small personal quantities and take no further action, if it is a first-time offence, or if the person is addicted. In case of serious crime act (sale, distribution) involving a significant quantity of cannabis, punishment can range from 1 to 10 years of imprisonment. However, the legislation does not exactly define small and significant quantity and a court decision is made on a case-by-case basis (30).

\section{DISCUSSION}

Results of our qualitative analysis provide overview on cannabis control legislative norms in the Visegrad Four (V4). Comparing situation in the V4 in the light of epidemiological data on cannabis use allows evaluation of the role of legislative norms in Central European countries with very similar political and economic development during last decades. On the other hand, these countries show several specific historical and cultural features.

Until the mid-1990s, legislation was rather uniform and resulted from a common history of communist totalitarian regime $(31,32)$. At that time, the substance use social scene was quite different due to limited availability as a result of restricted contacts with Western countries. The cannabis use was rather uncommon and started to significantly emerge together with political and 
social transition in the late $1980 \mathrm{~s}(31,33)$. The legislation related to substance use was rather similar in V4 countries keeping strict restrictive approach, except for the Czech Republic, where drug possession for personal use was decriminalised from 1990 to 1998. However, this was changed in 1999, when possession of drug including cannabis for personal use was criminalised (as a misdemeanour for "small amount" and a criminal offence in quantity "greater than small"). After 2009, the Czech Republic decriminalised cultivation of small amount of cannabis plants and further liberalised possession of cannabis since it introduced lower criminal penalties for unauthorised cannabis possession for personal use in quantity "greater than small" (34). The most conservative approach in drug policy changes has been seen in Slovakia (35).

However, the epidemiology of cannabis use in adolescents only partially corresponds with the above mentioned legislative changes. Prevalence of lifetime use clearly dominates in the Czech Republic and from 1995-2007, remarkable increase was shown. However, in 2007-2015, i.e. period when further decriminalisation was introduced, lifetime prevalence of cannabis in adolescents declined. On the other hand, similar trends can be identified in Slovakia (i.e. increase up to 2007), where the development of legislation has been quite different. But the prevalence in Slovakia never reached the levels seen in the Czech Republic. Despite similar legislative approach, prevalence of lifetime use in Hungary and Poland is clearly lower than in Slovakia, although increasing trend has been seen within the given period. The low prevalence in Hungary and Poland can be at least partially explained by higher level of religiosity in these countries, while inverse association between religiosity and health-risk behaviour in adolescents has been found (36).

The main idea of liberal legislative approach in the Czech Republic was to prevent stigmatisation of addicted persons and point attention to their treatment (37). According to previous experiences, conventional approach of "war against addictive drugs" has been shown ineffective and repressive measures alone did not lead to decrease of drugs supply and demands for them (37). Czech experiences should be inspirational for other V4 countries.

Considering specific issues of the legislation, definition of a small amount of cannabis deserves particular attention. This measure can prevent tough imprisonment sentences of first time users (mainly adolescents) with unserviceable effect failing their rehabilitation effects (38). On the other hand, decriminalization can lead to an increased supply resulting in declined prices and higher availability, particularly for adolescents $(9,39-41)$. The problem of negative impacts of decriminalization applies particularly to Slovakia, where the amount of the "usual single dose for personal use" is not exactly defined by the Act and thus the decision depends on the court's interpretation making ground for corruption or speculations. These issues should be kept in mind and decriminalisation legislative process should be very careful.

If we evaluate relationships between legislation and prevalence of cannabis use, not only one-side causative effect should be taken into consideration, i.e. effects of legislation on behaviour of people, but also reverse association can explain the situation. It means that in case of the Czech Republic, a widespread social tolerance towards cannabis use demonstrated by high prevalence rate can lead to political will to liberalize respective legislative norms. So, the question why the Czech Republic is so tolerant towards cannabis use is still open. Studies analysing attitudes towards addictive drugs show that Czech adolescents are much more tolerant compared to other European countries (42). We are aware that cannabis lifetime use alone does not provide complex picture of the problem. To better understand a complexity of the issue, other factors should be also taken into consideration, such as frequency of consumption or type of consumption, substances, data from general populations surveys, data from treatment, poly drug use, etc. $(43,44)$. However, such approach would make the analyses much more complicated, resulting in increased possibility of biased or misleading conclusions.

Our results are supported by other findings since the similar relationships can be seen also in other European countries (7). According to the 2017 EMCDDA report: cannabis legislation in Europe, in many European countries can be made a simple before and after comparison in relation to prevalence of cannabis use and legislation changes. However, according to trend prevalence data, no simple association can be seen between cannabis use prevalence and legal changes (7).

We consider a limitation of the study that only adolescent lifetime use was taken into account to describe the epidemiological situation. There are also other very important aspects (e.g. adult use, social-health effects, etc.), however, no validly comparable data on them are available and including of non-standardised ones into the analysis could be misleading. On the other hand, adolescents represent a particularly significant population group having impact on the whole community. Our analysis is based on ESPAD data. Beside this project there are also other possible sources of information on epidemiological situation, such as data from the European Monitoring Centre for Drugs and Drug Addiction, Health Behaviour in School Aged Children (HBSC) surveys, data from health care facilities, police, and other sectors of the society. However, different methods and target groups can result in inconsistency of the data with limited possibilities to compare them. So, to avoid these problems and to clearly point out differences across countries as well as changes over time, only one source of data was used. Moreover, we are aware that the analysis is based on aggregated data, so deeper analysis based on individual characteristics would evaluate possible causal links. However, despite this limitation, analysis clearly indicates different development across studied countries and demonstrates the role of social environment, including legislation and policy.

\section{CONCLUSION}

Eventually, our results indicate that legislation alone is not a crucial factor of cannabis use in a population but only one of numerous elements determining the overall epidemiological situation, such as historical and cultural background, economic and political situation, etc. Drug policy development in V4 countries is necessary to prevent negative impacts of risk behaviour among adolescents. In Europe, the trend is to liberate and to stop criminal proceedings in case of possession of small amounts of cannabis for personal use. It seems that the development of policy in many countries springs from the view when the cannabis addiction is considered rather a public health issue than criminal one (43). 


\section{Conflict of Interests}

None declared

\section{REFERENCES}

1. European Monitoring Centre for Drugs and Drug Addiction. European drug report (2014): trends and developments. Luxembourg: Publications Office of the European Union; 2016.

2. Ramström J. Adverse health consequences of cannabis use. A survey of scientific studies published up to and including the Autumn of 2003. Stockholm: National Institute of Public Health - Sweden; 2004.

3. Joshi M, Joshi A, Bartter T. Marijuana and lung diseases. Curr Opin Pulm Med. 2014;20(2):173-9.

4. Bachman J, O’ Malley PM, Schulenberg JE, Johnston L, Freedman-Doan $\mathrm{P}, \mathrm{Messersmith} \mathrm{EE}$. The education-drug use connection. How successes and failures in school relate to adolescent smoking, drinking, drug use, and delinquency. New York (NY): Lawrence Erlbaum Associates; 2008

5. Secades-Villa R, Garcia-Rodríguez O, Jin CJ, Wang S, Blanco C. Probability and predictors of the cannabis gateway effect: a national study. Int J Drug Policy. 2015 Feb;26(2):135-42.

6. Fergusson DM, Boden JM, Horwood LJ. Cannabis use and other illicit drug use: testing the cannabis gateway hypothesis. Addiction. 2006 Apr;101(4):556-69

7. European Monitoring Centre for Drugs and Drug Addiction. Cannabis legislation in Europe: An overview. Luxembourg: Publications Office of the European Union; 2017.

8. Room R, et al. Cannabis policy: moving beyond stalemate. Oxford: Oxford University Press; 2010.

9. Shi Y, Lenzi M, Ruopeng A. Cannabis liberalization and adolescent cannabis use: a cross - national study in 38 countries. PLoS ONE. 2015;10(11):e0143562. doi: 10.1371/journal.pone.0143562.

10. Reinarman C, Cohen D, Kaal L. The limited relevance of drug policy: cannabis in Amsterdam and in San Francisco. Am J Public Health. 2004;94(5):836-42.

11. Červený J, Chomynová, P, Mravčík V, van Ours JC. Cannabis decriminalization and the age of onset of cannabis use. Int J Drug Policy. 2017;43:122-9.

12. Mravčík V. (De)criminalisation of possession of drugs for personal use - a view from the Czech Republic. Int J Drug Policy. 2015;26(7):705-7.

13. Pardo B. Cannabis policy reforms in the Americas: a comparative analysis of Colorado, Washington, and Uruguay. Int J Drug Policy. 2014;25(4):727-35.

14. Ter Bogt T, Schmid H, Gabhainn SN, Fotiou A, Vollebergh W. Economic and cultural correlates of cannabis use among mid-adolescents in 31 countries. Addiction. 2006 Feb;101(2):241-51

15. Kážmér L, Csémy L, Ružbarská I, Pavelka J, Hamřík Z, Kalman M. Trends in lifetime cannabis use among Czech school-aged children from 2002 to 2014. Cent Eur J Public Health. 2017 Jul;25 Suppl 1:S47-S50.

16. Hibell B, Andersson B, Bjarnason T, Kokkevi A, Morgan M, Narusk A. The 1995 ESPAD report: alcohol and other drug use among students in 26 European countries. Stockholm: Swedish Council for Information on Alcohol and Other Drugs; 1997.

17. Hibell B, Andersson B, Ahlström S, Balakireva O, Bjarnason T, Kokkevi A, et al. The 1999 ESPAD report: alcohol and other drug use among students in 30 European countries. Stockholm: Swedish Council for Information on Alcohol and Other Drugs; 2000.

18. Hibell B, Andersson B, Bjarnason T, Ahlström S, Balakireva O, Kokkevi A, et al. The ESPAD report 2003: alcohol and other drug use among students in 35 European countries. Stockholm: Swedish Council for Information on Alcohol and Other Drugs; 2004.

19. Hibell B, Guttormsson U, Ahlström S, Balakireva O, Bjarnason T, Kokkevi A, at al. The 2007 ESPAD report: substance use among students in 35 European countries. Stockholm: Swedish Council for Information on Alcohol and Other Drugs; 2009.

20. Hibell B, Guttormsson U, Ahlström S, Balakireva O, Bjarnason T, Kokkevi A, at al. The 2011 ESPAD report: substance use among students in 36 European countries. Stockholm: Swedish Council for Information on Alcohol and Other Drugs; 2012.
21. European School Survey Project on Alcohol and Other Drugs. ESPAD Report 2015: results from the European School Survey Project on Alcohol and Other Drugs. Luxembourg: Publications Office of the European Union; 2016.

22. European legal database on drugs (ELDD) [Internet]. Lisbon: European Monitoring Centre for Drugs and Drug Addiction [cited 2016 Dec 8]. Available from: http://www.emcdda.europa.eu/eldd.

23. Radimecký J. Rhetoric versus practice in Czech drug policy. J Drug Issues. 2007;37(1):11-44.

24. Zábranský T, Miovský M, Gajdošíková H, Mravčík V. Impact analysis project of new drugs legislation: summary final report. Prague: Office of the Czech Government Secretariat of the National Drug Commission; 2001

25. Zeman P. Legislation and practice concerning prosecution of drug offenses in the Czech Republic. J Drug Issues. 2007;37(1):45-72.

26. Act No. 140 Penal Code. Sbírka zákonů ČR. 1961 Dec 8;Part 65:465-512. (In Czech).

27. Act No. 40 Penal Code of January 8, 2009. Sbírka zákonů ČR. 2009 Feb 9;Pt 11:354-464. (In Czech).

28. Act No. 300 Penal Code of May 20, 2005, as amended. Zbierka zákonov SR. 2005 Jul 2;Pt 129;3002-90. (In Slovak).

29. Act C Penal Code of 2012. Magyar Közlöny. 2012 Jul 13;Pt 92:1-122. (In Hungarian).

30. Act No. 553 Penal Code of June 6, 1997, as amended. Dziennik ustaw RP. 1997 Aug 2;Pt 88:2677-716. (In Polish.)

31. Grund JP, Zabransky T, Irwin KS, Heimer R. Stimulant use in Central and Eastern Europe: how recent social history shaped current drug consumption patterns. In: Pates R, Riley D, editors. Interventions for amphetamine misuse. Chichester: Blackwell Pub./Addiction Press; 2010. p. 173-203.

32. Kokkevi A, Nic Gabhainn S, Spyropoulou M; Risk Behaviour Focus Group of the HBSC. Early initiation of cannabis use: a cross-national European perspective. J Adolesc Health. 2006 Nov;39(5):712-9.

33. Becker GS, Murphy KM, Grossman M. The market for illegal goods: the case of drugs. J Polit Econ. 2006;114(1):38-60.

34. Mravčík V, Chomynová P, Grohmannová K, Nečas V, Grolmusová L, Kiššová L, et al. Annual report: The Czech Republic - 2012 drug situation. Prague: Office of the Government of the Czech Republic; 2013.

35. Klobucký R. Why is a restrictive drug policy promoted in Slovakia? In: 6th Olomouc Sociological Autumn Conference; 2016 Oct 19-21; Olomouc, Czech Republic. (In Slovak.)

36. Pitel L, Madarasova Geckova A, Kolarcik P, Halama P, Reijneveld SA, van Dijk JP. Gender differences in the relationship between religiosity and health-related behaviour among adolescents. J Epidemiol Community Health. 2012 Dec;66(12):1122-8.

37. Csete J. A balancing act: Policymaking on illicit drugs in the Czech Republic. New York: Open Society Foundations; 2012.

38. Room R. Legalizing a market for cannabis for pleasure: Colorado, Washington, Uruguay and beyond. Addiction. 2014;109(3):345-51.

39. Álvarez A, Gamella JF, Parra I. The legalization of cannabis derivatives in Spain: Hypothesis on a potential emerging market. Adicciones. 2017;29(3):195-206

40. Hopfer C. Implications of marijuana legalization for adolescent substance use. Subst Abuse. 2014;35(4):331-5.

41. Ogrodnik M, Kopp P, Bongaerts X, Tecco JM. An economic analysis of different cannabis decriminalization scenarios. Psychiatr Danub. 2015 Sep;27 Suppl 1:S309-14

42. Csémy L, Lejčková P, Sadílek P. Substance use among Czech adolescents: an overview of trends in the international context. J Drug Issues. 2007;37(1):119-32.

43. Ventura E, Wagner $H$, Rossi C. New indicators of health among adolescent drug users and evaluation of drug policies comparing countries. Epidemiol Biostat Public Health. 2015;12(1 Suppl 1).

44. Kuntsche E, Simons-Morton R, Fotiou A, Ter Bogt T, Kokkevi A; Health Behavior in School-Aged Children Study. Decrease in adolescent cannabis use from 2002 to 2006 and links to evenings spent out with friends in 31 European and North America countries and regions. Arch Pediatr Adolesc Med. 2009 Feb;163(2):119-25.

Received December 23, 2016 Accepted in revised form November 14, 2017 